\title{
DINAMIKA SISTEM POLITIK OTORITARIANISME ORDE BARU
}

\author{
Yusa' Farchan \\ Program Studi Ilmu Pemerintahan Universtas Sutomo, Serang, Banten \\ email:yusak1982@gmail.com
}

Paper Accepted: 25 Desember 2021
Paper Reviewed: 02-08 Januari 2022
Paper Edited: 09-19 Januari 2022
Paper Approved: 20 Januari 2022

\begin{abstract}
ABSTRAK
Beragam studi yang pernah dilakukan mengenai Orde Baru, pada umumnya melahirkan beberapa label tentang politik Indonesia. Beberapa label tersebut mencakup antara lain; "state-qua-state" yang dipopulerkan Benedict Anderson, "bureaucratic poliity" oleh Karl D. Jackson, "bureaucratic pluralism" oleh Donald Emmerson, "bureaucratic authoritarianism" oleh Dwight King, dan "limited pluralism"-nya William Liddle (Maclntyre 1990). Meskipun terdapat perbedaan pendapat antar mereka dalam menggambarkan politik Orde Baru, namun umumnya mereka sependapat bahwa aparat negara mendominasi arena politik dan mengontrol masyarakat. Kajian ini ingin menelaah bagaimana dinamika sistem politik otoritarianisme yang telah dipraktikkan Orde Baru. Selain itu, kajian ini juga ingin menjawab pertanyaan penting mengapa pemerintahan Soeharto memilih jalan otoritarianisme sebagai sistem politiknya?. Kajian ini menggunakan metode kualitatif dengan pendekatan studi kasus. Studi kasus yang diangkat adalah format sistem politik otoritarianisme Orde Baru. Analisis data dilakukan dengan pendekatan analisis deskriptif. Adapun teknik pengumpulan data dilakukan melalui studi pustaka dan dokumentasi teks-teks yang berkaitan dengan objek penelitian. Dari hasil kajian ditemukan beberapa hal. Pertama, kekuasaan politik Orde Baru yang yang bercorak otoriter setidaknya berakar dari lima sumber utama, yaitu; represi; kekuasaan material yang terkonsentrasi; wacana politik partikularistik; subordinasi bisnis terhadap negara; dan pengendalian birokrasi sipil dan militer. Kedua, dari aspek stabilitas, Indonesia di bawah Orde Baru dapat dikatakan stabil karena gejolak politik, ekonomi, dan sosial tidak terjadi, atau setidaknya jarang terjadi sepanjang pemerintahan Orde Baru. Dengan demikian, stabilitas Indonesia di bawah Soeharto dapat dikategorikan ke dalam Sistem Otoritarianisme Terbuka. Ketiga, jalan otoritarianisme sengaja dipilih Soeharto dengan tujuan untuk mempermudah agenda-agenda pembangunan ekonomi. Dalam konteks ini, diperlukan stabilitas politik yang terkendali melalui format sentralisme politik untuk mempermudah alat kontrol bagi penyelenggaraan kekuasaan.
\end{abstract}

Kata Kunci; Otoritarianisme; Orde Baru; Soeharto 


\section{PENDAHULUAN}

Selama kurang lebih dua puluh tiga tahun terakhir, sistem politik Orde Baru yang digambarkan oleh para ahli politik, tidak mengalami perubahan atau pergeseran berarti. Berbagai studi yang pernah dilakukan, pada umumnya melahirkan beberapa label tentang politik Indonesia. Beberapa label tersebut mencakup antara lain; "state-qua-state" yang dipopulerkan Benedict Anderson, "bureaucratic poliity" oleh Karl D. Jackson, "bureaucratic pluralism" oleh Donald Emmerson, "bureaucratic authoritarianism" oleh Dwight King, dan "limited pluralism"nya William Liddle (Maclntyre 1990). Meskipun terdapat perbedaan pendapat antar mereka dalam menggambarkan politik Orde Baru, namun umumnya mereka sependapat bahwa aparat negara mendominasi arena politik dan mengontrol masyarakat.

Pada level analisis yang lebih mikro, para analis juga percaya bahwa politik Indonesia semakin ditandai dengan sentralisasi yang semakin dominan. Apabila pada awal Orde Baru, politik Indonesia berada di bawah kendali kekuatan militer sebagai institusi, maka sejak awal 1980-an, politik Indonesia semakin tersentralisasi pada kepemimpinan personal Soeharto (Pratikno, 1998; 19).

Salah satu kelebihan pemerintahan Orde Baru adalah kemampuannya dalam menciptakan stabilitas politik dengan pemerintahan yang kuat. Stabilitas ini membawa Orde Baru semakin berhasil membangun landasan bagi keberhasilan di sektor lainnya, terutama masuknya investasi asing yang membawa pertumbuhan ekonomi makro secara gemilang.

Dalam paradigma kekuasaan Orde Baru, stabilitas (politik) diperlukan untuk mempermudah agenda-agenda pembangunan (ekonomi). Oleh karena itu, restrukturisasi politik menjadi kata kunci penting dalam penataan atau pembangunan sistem politik Orde Baru berbasis sentralisme dengan harapan bahwa pembangunan ekonomi dapat berjalan secara akseleratif. Format sentralisme inilah yang pada akhirnya menghasilkan corak kekuasaan politik otoritarianisme dalam kurun waktu 32 tahun, meskipun kekuasaan Soeharto pada akhirnya tumbang oleh gerakan mahasiswa dan elemen sipil lainnya pada tahun 1998.

Kajian ini ingin menelaah bagaimana dinamika sistem politik otoritarianisme yang telah dipraktikkan Orde Baru. Selain itu, kajian ini juga ingin menjawab pertanyaan penting mengapa pemerintahan Soeharto memilih jalan otoritarianisme sebagai sistem politiknya?

\section{METODE}

Kajian ini menggunakan metode kualitatif deskriptif. Pendekatan yang digunakan dalam kajian ini adalah pendekatan studi kasus. Studi kasus yang diangkat adalah format sistem politik otoritarianisme Orde Baru. Analisis data dilakukan dengan pendekatan analisis deskriptif. Adapun teknik pengumpulan data dilakukan melalui studi pustaka dan dokumentasi teks-teks yang berkaitan dengan objek penelitian.

\section{PEMBAHASAN}

\section{Dinamika Sistem Politik Otoritarianisme Orde Baru}

Untuk memahami dinamika dan potret sistem politik otoritarianisme Orde Baru, perlu dikaji tentang sumber-sumber kekuasaan sistem politik otoritarianisme tersebut. Dalam hal ini, kekuasaan politik Orde Baru yang yang bercorak otoriter setidaknya berakar dari lima sumber utama, yaitu; represi; kekuasaan material yang terkonsentrasi; wacana politik partikularistik; subordinasi bisnis terhadap negara; dan pengendalian birokrasi sipil dan militer. Kelima sumber kekuasaan tersebut akan diuraikan sebagai berikut.

\section{a) Represi}

Terkait dengan sumber kekuasaan pertama yaitu represi, perlu dicatat bahwa di awal 1970-an ketika berupaya untuk membangun konsolidasi politik, kekerasan adalah instrumen utama yang dipakai oleh pemerintah Orde Baru untuk mencapai stabilitas politik. Aktivitas politik di periode sebelumnya dihancurkan. Selain itu, kekuatan oposisi juga dibatasi. Untuk keperluan tersebut, sejumlah badan intelijen kemudian dibentuk untuk 
melakukan kontrol terhadap masyarakat, seperti BAIS (Badan Intelijen Strategis) yang terdiri dari unsur-unsur tentara, BAKIN (Badan Koordinasi Intelijen) yang banyak diisi oleh orang sipil, institusi pendidikan seperti Lembaga Sandi Negara, atau Jaksa Agung Muda bidang intelejen. Badan yang menyentuh sampai tingkat pedesaan adalah BAIS, Ditjensospol (Direktorat Jenderal Sosial Politik), dan Kopkamtib (Komando Keamanan dan Ketertiban). Kopkamptib kemudian berubah menjadi Bakorstranas (Badan Koordinasi Strategis Nasional).

BAIS, yang didirikan tahun 1983, berhubungan langsung dengan markas besar ABRI dan bertugas menganalisa situasi sosial-politik nasional dan berhubungan erat dengan badan ABRI yang mengurusi kontrol sosial dan politik. Sementara itu, Ditjensospol yang berada di bawah koordinasi Departemen Dalam Negeri, merupakan badan intelijen yang membantu kelancaran Departemen ini. Tugasnya membantu pemerintah lokal memelihara stabilitas daerah masingmasing. Di bawah Ditjensospol terdapat badan sejenis untuk tingkat provinsi dan kabupaten/kotamadya, yang antara lain bertugas untuk menyaring calon anggota DPRD, calon Pegawai Negeri, dan mengeluarkan ijin bagi kegiatan penelitian.

Lembaga represi lainnya adalah Kopkamtib yang menempati posisi sentral selama dua dekade sebelum diganti oleh Bakorstanas tahun 1988. Dengan Keputusan Presiden tahun 1969, badan ini tidak hanya bertugas membersihkan sisasisa PKI, tapi juga turut menangani persoalan-persoalan yang mengancam keamanan nasional, termasuk mengawasi pers dan aktivitas mereka yang kritis terhadap pemerintah. Kopkamtib adalah organisasi dengan kekuasaan tanpa batas, dari tingkat nasional sampai lokal. Laksusda (Pelaksana Khusus Daerah) adalah Kopkamtib di tingkat daerah. Kopkamtib selanjutnya menjadi badan paling represif dan menakutkan yang selalu turut menyelesaikan persoalan politik di setiap organisasi kemasyarakatan, bahkan melakukan penangkapan kapan saja mereka mau.
Di sisi lain, penerapan UU Antisubversi (UU No 5/ 1969) menjadi semacam legitimasi tindakan pemerintah atas nama negara untuk melindungi munculnya ideologi lain dan ancaman politik yang membahayakan Pancasila. Stabilitas dan pembangunan ekonomi telah dimanipulasi sedemikian rupa untuk mengontrol masyarakat, khususnya mereka yang kritis terhadap pemerintah. Yang dimaksud dengan tindakan subversif sendiri mencakup banyak aktivitas yang mengancam keberadaan pemerintah, yang tidak tegas batasnya (Hart 1987: 198-199). Dengan begitu luas dan tidak jelasnya definisi tindakan subversi, banyak aktivis yang dengan mudah dimasukkan ke dalam kategori subversif, tergantung bagaimana interpretasi pengadilan terhadap dirinya. Hukum ini selanjutnya menjadi dasar yang sah untuk praktik represifitas negara terhadap warganya.

\section{b) Kientelisme Ekonomi}

Sumber utama kedua yang digunakan Orde Baru untuk membangun otoritarianisme politik adalah kekuasaan material yang terkonsentrasi atau disebut klientelisme ekonomi. Klientelisme ekonomi berhasil dilakukan karena melimpahnya sumber daya ekonomi dari hasil ekspor minyak dan hasil alam lainnya. Dengan sumber daya inilah, Soeharto secara efektif mampu membeli dukungan dari elite politik dan masyarakat luas (Pratikno, 1989; 21).

Karena kesulitannya dalam memperoleh dukungan politik murni dari masyarakat, Orde Baru mengembangkan pola "money politics" untuk mendapatkan loyalitas etite politik. Insentif-insentif ekonomi kemudian ditawarkan kepada elite politik yang loyal. Sebaliknya, pembatasan akses ekonomi diberikan sebagai sangsi kepada mereka yang "melawan" dan mengambil jarak dengan kekuasaan.

Insentif tersebut antara lain berupa keistimewaan dukungan politik terhadap bisnis para loyalis, penguasaan proyekproyek pembangunan dari pemerintah, dan keleluasaan untuk melakukan korupsi uang negara. Walaupun telah mengakibatkan inefisiensi ekonomi dan tingkat korupsi 
yang luar biasa, strategi ini terbukti menjadi salah satu instrumen ampuh bagi pemerintah Orde Baru untuk membangun loyalitas elite politik.

Strategi tersebut dijalankan melalui beberapa cara utama (Pratikno, 1989; 22). Pertama, proses negara-isasi pengelolaan sumber daya ekonomi. Dengan dasar pasal 33 UUD 1945, pemerintah dan elite penguasa berusaha secara ekspansif untuk memiliki sumber daya ekonomi tersebut, atau paling tidak mengontrol pengelolaannya secara ketat. Penguasaan terhadap kekayaan yang melimpah, seperti hutan dan minyak telah membuat negara menjadi pilar utama aktivitas ekonomi nasional. OIeh karena itu, proses negaraisasi ini terus menanjak sejak pertengahan 1970-an sejalan dengan peningkatan ekspor kekayaan alam Indonesia. Kedua, pemerintah melakukan sentralisasi pengelolaan sumber daya ekonomi pada pemerintah pusat dan menempatkan pemerintah daerah sekedar sebagai pelaksana dan bahkan penonton.

Ketiga, mekanisme alokasi sumber daya dilakukan dengan menempatkan pemerintah pusat pada posisi yang otonom tanpa adanya pengaruh yang berarti dari parlemen dan masyarakat. $\mathrm{Hal}$ ini diperparah oleh sistem pengalokasian yang tidak baku dan tidak transparan yang membuat elite pemerintah pusat bisa memanfaatkan alokasi sumber daya keuangan untuk pembelian dukungan bagi pemerintah pusat maupun bagi elitnya. Keempat, diciptakannya ketergantungan masyarakat dan individu daerah kepada negara di tingkat pusat. Bukan saja pemerintah daerah saja yang harus menunjukkan loyalitasnya kepada pusat agar memperoleh alokasi proyek yang memadai, tetapi individu-pun harus membangun patronase kepada elite dan pemerintah pusat. Pegawai negeri digaji dengan standar yang sangat rendah yang tidak memungkinkan mereka untuk hidup normal. Namun demikian, pegawai negeri diberi keleluasaan untuk memperoleh tambahan income dari "proyek" yang sporadis yang dikontrol oleh pemerintah atau elite (atasan).

Secara bersamaan, empat hal di atas telah membuat elite Orde Baru "membeli" dukungan dari masyarakat. Mekanisme ini bersenyawa dengan mekanisme represi politik yang dikendalikan oleh militer, birokrasi sipil dan peradilan, serta kontrol terlembaga kepada masyarakat melalui strategi korporatisme negara.

\section{c) Wacana Partikularistik}

Sumber kekuasaan politik otoritarianisme Orde Baru ketiga adalah ideologisasi definisi partikularistik terhadap segala aspek kehidupan bernegara. Tujuannya adalah untuk melegitimasi otoritarianisme.

Definisi partikularistik ini misalnya terdapat dalam definisi tentang demokrasi yang diberi nama Demokrasi Pancasila, definisi tentang hak asasi manusia, tentang tanggung jawab warga negara, dan lain-lain. Definisi-definisi tersebut telah membangun "keabsahan" politik rezim otoriter Orde Baru secara moral. Keabsahan ini diperoleh dengan mempermainkan standar moralitas, dan bukan memperbaiki diri untuk memenuhi standar moral tertentu.

Jika politik represi (management of fear), dan klientelisme ekonomi adalah mekanisme kontrol terhadap perilaku politik, maka politik wacana dapat dikatakan sebagai mekanisme kontrol terhadap persepsi dan pola pikir masyarakat (partisipan politik).

\section{d) Subordinasi Bisnis Terhadap Negara}

Sumber energi otoritarianisme Orde Baru yang keempat adalah subordinasi bisnis terhadap negara. Dalam perspektif Robinson (1988), yang dimaksud dengan subordinasi bisnis terhadap negara adalah Orde Baru cenderung memposisikan sektor bisnis bergantung pada negara. Kondisi ini semakin diperburuk oleh hadirnya apa yang disebut Robinson (1988) sebagai politicio-bureaucrat entrepreneurs yaitu para pengusaha yang berstatus sebagai putra-putri pejabat, atau mereka yang memiliki pertalian kerabat, maupun relasi kroni dengan para pejabat negara. Hal ini berakibat pada semakin melemahnya fundamental perekonomian Indonesia karena berorientasi pada kepentingan ekonomi jangka pendek. Dapat dikatakan 
bahwa hidup matinya bisnis akan bergantung pada hidup matinya negara (Hidayat, 2021).

Subordinasi bisnis terhadap negara ini ditandai misalnya dengan penunggalan kelompok-kelompok profesi dan kepentingan yang ke bawah menempati posisi penting di hadapan anggotanya, namun ke atas, organisasi ini sangat rentan terhadap intervensi negara. Organisasi perwakilan ini terdiferensiasi berdasarkan fungsi dan profesi anggotanya (Maclntrye 1990:23). Pengusaha, buruh, petani, guru, dan wartawan diwadahi organisasiorganisasi profesi yang dikontrol ketat oleh pemerintah. Tiap organisasi harus mengontrol anggotanya dan memobilisasi dukungan untuk pemerintah. Selanjutnya bisa dibayangkan bagaimana semakin terbatasnya partisipasi masyarakat.

Organisasi-organisasi tersebut ada yang memang dibentuk Orde Baru dan ada yang merupakan hasil campur tangan. PWI, GUPPI dan Sekber Golkar tergolong yang kedua (campur tangan). Organisasiorganisasi ini mendapat "fungsi" baru setelah diintervensi. Sementara itu, KADIN, KORPRI adalah organisasi dengan kategori pertama. Hampir semua organisasi telah dicampuri pemerintah, terutama saat pemilihan ketua.

\section{e) Pengendalian Birokrasi Sipil dan Militer}

Sumber kekuasaan otoritarianisme Orde Baru yang kelima adalah pengendalian birokrasi sipil dan militer. Hal ini dilakukan sebagai bagian dari upaya konsolidasi politik Orde Baru. Sebagaimana diketahui, salah satu masalah pokok yang ada dalam sistem pemerintahan Orde Baru adalah bagaimana menata sistem politik yang handal untuk mendukung pembangunan ekonomi serta bidang-bidang lainnya. Meskipun awalnya pusat perhatian Orba tertuju pada penanggulangan dan pembangunan ekonomi, tetapi hal lain yang sangat penting di samping pertahanan dan keamanan adalah penataan dan pembangunan politik (Alfian, 1990; 209210).

Dalam birokrasi sipil misalnya, awalnya unsur-unsur PKI dan Soekarno dibersihkan. Rekrutmen pejabat baru juga dibatasi dan diawasi. Selain itu, masa-masa pensiun juga dipercepat. Para birokrat yang menjalin hubungan dengan partai, digantikan warga sipil yang bebas partai. Aparat birokrasi dibuat loyal hanya kepada pucuk pimpinan eksekutif. Jaringan birokrasi dibangun dengan gaya militer, hierarkis dengan pakaian dinas dan atribut seragam. Penjelasan mendalam mengenai hal ini, dapat dilihat dalam Donald K. Emmerson, "The Bureaucracy in Political Context: Weakness in Strength", dalam Karl D. Jackson dan Lucian W. Pye (ed) (1978; 82-136).

Orde Baru berupaya memanfaatkan birokrasi sebagai primium mobile alias penggerak utama pembangunan (Mas'oed, 1989; 150). Hal ini dilakukan dengan cara menciptakan tipe birokrat yang lebih aktif dan tanggap terhadap kepentingan Orba. Birokrasi juga difungsikan secara luas dan rapi untuk memuluskan program-program pembangunan. Gaji pejabat dinaikkan dan fasilitas penunjang disediakan untuk merangsang produktifitas. Hal ini mengingat bahwa di era sebelumnya, birokrasi lama banyak diisi orang-orang PNI (Partai Nasionalis Indonesia), yang mengandalkan dukungan dari Pamong Praja. Untuk mengikis pengaruh PNI, Depdagri menghapus Korps Pegawai Negeri Sipil (Pamong Praja) pada tahun 1996 yang merupakan buatan Orde Lama, dan menggantinya dengan Korps Karyawan Kementerian Dalam Negeri.

Pada tahun 1970, Kopkarmendagri diganti menjadi Korpri (Korps Pegawai Republik Indonesia) dan semua birokrat diwajibkan menjadi anggotanya di bawah loyalitas tunggal pada pemerintah. Monoloyalitas ini dalam praktiknya tereduksi menjadi loyal kepada Golkar yang merupakan mesin politik Orde Baru. Pada tahun 1976, dikeluarkan Peraturan Pemerintah No.20 Tahun 1976 yang mensyaratkan izin atasan bagi PNS (Pegawai Negeri Sipil) yang mau menjadi anggota organisasi sosial politik tertentu.

Tidak hanya itu, kendali birokrasi juga ditempuh dengan proliferasi perwiraperwira ABRI ke semua lini birokrasi, baik di pusat maupun daerah. Sejak Kabinet Pembangunan I tahun 1968 dibentuk, 
mayoritas departemen dan badan pemerintahan dikepalai oleh perwira ABRI. Begitu juga dengan pos-pos kepala daerah tingkat I dan II. Pada tahun 1960, hanya beberapa Gubernur saja yang berasal dari ABRI, tetapi di tahun 1968, 68\% para gubernur adalah perwira ABRI. Angka tersebut meningkat menjadi $92 \%$ di awal tahun 1970-an. Sedangkan dalam tahun 1968, 59\% dari para bupati adalah perwira ABRI (Mas'oed, 1989; 151-152).

Untuk memperkuat cengkeraman atas birokrasi, dibentuk jaringan aparatur intelijen dan keamanan yang ditempatkan dalam setiap bidang birokrasi utama dan setiap ibukota provinsi. Untuk keperluan ini, dibentuk tiga badan yaitu: Kopkamtib (Komando Operasi Pemulihan Keamanan dan Ketertiban), Opsus (Operasi Khusus), dan Bineg (Bina Intelijen Negara). Strategi ini tidak hanya efektif mengendalikan birokrasi, tetapi juga memunculkan dominasi ABRI yang luas di dalamnya.

Perlu dicatat bahwa birokrasi Orde Baru adalah instrumen politik yang begitu efektif memobilisasi massa untuk memelihara format politik Orba. Menurut Afan Gaffar (1999; 235-237), selama kekuasan Orba, instrumen kekuasan birokrasi diwujudkan ke dalam tiga pola. Pertama; pada setiap pemilu, dukungan diberikan secara langsung pada Golkar. Pada pemilu 1997 misalnya, tidak kurang 1,1 juta PNS memberikan suaranya kepada Golkar. Jika ditambah dengan suara dari keluarga mereka, Golkar akan mendapat sekitar 10 juta suara dari PNS dan keluarganya. Kalau satu kursi bernilai 400.000 suara, maka PNS menyumbangkan sebanyak 20 kursi buat Golkar. Pada Pemilu 1997, Partai Golkar memperoleh 325 dari 425 kursi DPR RI yang diperebutkan atau sekitar 76,47\% kursi. Kedua, birokrasi mendominasi semua struktur panitia pemilu untuk menjamin kemenangan Golkar. Dari Lembaga Pemilihan Umum (LPU), Panitia Pemilihan Indonesia (PPI), PPD Tingkat I, PPD Tingkat II, Panitia Pemungutan Suara (PPS), hingga Kelompok Penyelenggara Pemungutan Suara (KPPS), semuanya didominasi oleh biokrasi. Ketiga, dalam setiap pemilu, birokrasi adalah penyedia dana bagi kemenangan Golkar, lewat para pejabat daerah dengan memotong biaya proyek tertentu.

Catatan penting berikutnya adalah bahwa seraya membenahi birokrasi, Orde Baru juga mengendalikan konflik di tubuh militer, terutama Angkatan Darat (AD). Perhatian tertuju pada perwira yang tidak suka pada kemunculan Soeharto yang terlalu cepat dalam kekuasaan, sementara mereka ini masih duduk di pos-pos militer yang penting. Meskipun mereka menerima kepemimpinan Soeharto dan tidak menghendaki perang saudara, mereka juga siap memanfaatkan setiap titik lemah Soeharto. Menghadapi tantangan itu, menurut Harold Crouch (1986; 249), Soeharto secara serentak menerapkan dua strategi, yaitu pertama, tetap menggunakan pasukan yang melakukan pembersihan pasca kudeta serta mengarahkannya pada sisa-sisa PKI, para pendukung Soekarno, dan kelompok-kelompok lain yang menentang kepemimpinan $\mathrm{AD}$, baik dari kalangan partai-partai non komunis maupun di kalangan AD. Kedua, Soeharto memilih prinsip Jawa "alon-alon asal kelakon" atau "biar lambat asal jalan" untuk menghadapi lawan-lawan militernya yang mungkin bisa mengerahkan pasukan mereka.

Berikutnya, penataan militer dilakukan secara sistematis, dimulai dengan pembersihan para perwira pro-Soekarno atau yang "nyempal", hingga perubahan struktur organisasi ABRI. Pembersihan para perwira Soekarnois dan pendukung Orde Lama pertama-tama dilakukan pada Angkatan Darat, kemudian menyusul angkatan-angkatan lain, termasuk kepolisian.

Agar dominasi sistemik para perwira militer absah, diberlakukan doktrin dwi fungsi ABRI. Dalam hal ini, ditegaskan bahwa tentara Indonesia berbeda dengan tentara negara-negara lain, karena tentara Indonesia mengemban misi khusus, yakni tanggungjawab militer sekaligus tanggungjawab pada semua bidang yang penting bagi pelaksanaan negara. Melalui doktrin ini, militer merasa memiliki justifikasi untuk terlibat dalam bidang bidang non-militer yang lazimnya menjadi wilayah sipil. 


\section{Stabilitas dalam Sistem Otoritarianisme Tertutup dan Tebuka}

Dalam sistem pemerintahan negaranegara di dunia, terdapat dua jenis karakter sebuah rezim, yaitu negara yang stabil karena tertutup dan negara yang stabil karena terbuka. Idealnya, negara yang stabil karena terbuka lebih baik dibandingkan negara yang stabil karena tertutup.

Dalam analisis Bremmer (2013), terdapat dua faktor penentu kualitas sebuah pemerintahan, yakni keterbukaan dan kestabilan. Keterbukaan mengukur sejauh mana sebuah negara selaras dengan arus-arus globalisasi yang saling-silang serta seberapa jauh negara tersebut menjamin kebebasan warga negaranya dalam berekspresi dan memperoleh informasi. Sementara itu, kestabilan merujuk pada kemampuan negara bertahan dari guncangan dan kemampuannya untuk tidak membuat guncangan-guncangan.

Dari kategorisasi itu, Bremmer memberikan contoh negara-negara, seperti Korea Utara, Kuba, dan Irak sebagai negara yang berada pada sisi paling kiri dari Kurva J, yakni negara stabil tetapi tertutup. Sebaliknya, negara-negara yang dikategorikan sebagai negara 'agak terbuka', tetapi berpotensi menjadi tidak stabil adalah Iran, Arab Saudi, dan Rusia. Afrika Selatan dan Yugoslavia adalah contoh negara yang berada di paling bawah dari Kurva J. Teori 'Kurva J' menyediakan kerangka analisis yang memadai untuk memahami bagaimana negara-negara runtuh atau bertahan dalam proses menuju pemerintahan terbuka. Disebut 'Kurva J' karena teori itu digambarkan dalam bentuk grafik dengan sumbu vertikal yang mengukur kestabilan dan sumbu horizontal yang mengukur keterbukaan politik dan ekonomi terhadap dunia luar (Ian Bremmer, 2013).

Negara-negara yang berada di sisi paling kanan Kurva J atau masuk dalam kategori negara stabil dan terbuka, contohnya adalah Turki, Israel, dan India. Untuk Cina, Bremmer menempatkannya di sisi kiri Kurva J dengan alasan Cina masih relatif tertutup sekalipun ekonominya terbuka, namun stabil.

Perlu dicatat bahwa dalam sistem otoriter yang tertutup sekalipun, kestabilan tetap ada bahkan mungkin dengan derajat yang lebih stabil dibandingkan sistem demokratis. Kendali terpusat berfungsi seperti peredam kejut yang menyerap goncangan secara efektif dan efisien. Sebaliknya, dalam sistem demokratis belum tentu terdapat kestabilan karena begitu kran kebebasan dibuka, berbagai gejolak muncul secara tiba-tiba. Hanya saja, kestabilan pada rezim otoriter sangat tergantung pada pribadi seorang pemimpin. Selama sang pemimpin masih hidup, kestabilan bisa dipertahankan.

Akan tetapi, jika suksesi politik tidak mampu mempertahankan 'kultus individu', bisa dipastikan rezim tersebut akan jatuh pada lereng paling bawah sebagaimana digambarkan dalam Kurva J. Dengan kata lain, akan mengalami fase ketidakstabilan yang parah.

Menurut Bremmer (2013; 18), kediktatoran mustahil bisa bertahan lama karena Otoritarianisme bertentangan dengan hasrat alami manusia untuk bebas. Masyarakat yang hidup di bawah bayangbayang represi pemerintah ibarat bom waktu yang suatu saat akan meledak. Begitu momentum itu tiba, hasrat terpendam tadi meledak tanpa kendali. Jika itu terjadi, negara bekas kediktatoran itu akan jatuh di kurva paling bawah dan menjadi lahan subur bagi munculnya sumber-sumber ancaman, seperti terorisme dan senjata pemusnah massal. Dalam fase transisi menuju demokrasi, negara menjadi lebih agresif dan tak jarang memicu perang dengan negara lain.

Berbeda dengan kestabilan yang terdapat, baik pada rezim otoriter maupun demokratis, keterbukaan hanya mungkin dijamin oleh pemerintahan demokratis. Sistem demokrasi menjamin kebebasan berekspresi warganya dan mengakses informasi dari mana saja. Memang, keterbukaan tidak bisa menjamin kestabilan. Akan tetapi, kestabilan yang didukung dengan keterbukaan lebih baik dan tahan lama karena dua alasan. Pertama, negara yang stabil dan terbuka akan terhindar dari guncangan yang bisa menyeretnya ke titik terendah dari Kurva J. Kedua, negara yang stabil dan terbuka relatif lebih ramah dalam hal kebijakan luar negerinya sehingga akan berkontribusi 
terhadap perdamaian internasional. Hal ini jelas berbeda dengan negara otoritertertutup yang cenderung bersikap agresif untuk menarik perhatian dunia internasional.

Dalam konteks Indonesia, jika mengikuti kurva J tersebut, maka dari aspek stabilitas, Indonesia di bawah Orde Baru dapat dikatakan stabil karena gejolak politik, ekonomi, dan sosial tidak terjadi, atau setidaknya jarang terjadi sepanjang pemerintahan Orde Baru. Dengan demikian, stabilitas Indonesia di bawah Soeharto dapat dikategorikan ke dalam Sistem Otoritarianisme Tebuka.

\section{Mengapa Soeharto Memilih Jalan Otoritarianisme?}

Sebagaimana telah disinggung sebelumnya bahwa peralihan kekuasaan dari Orde Lama ke Orde Baru menyisakan masalah pelik terkait dengan instabilitas politik dan mandegnya agenda-agenda pembangunan ekonomi Indonesia di bawah kekuasaan Soekarno. Oleh karenanya, pada awal kekuasaan Orde Baru, politik Indonesia kemudian berada di bawah kendali kekuatan militer sebagai institusi, meskipun pada 1980-an, politik Indonesia semakin tersentralisasi pada kepemimpinan personal Soeharto.

Konsolidasi kekuasaan baru Orba memberikan tempat yang sangat luas bagi militer untuk mendominasi proses berjalannya politik. Harold Crouch (1986) menjelaskan, dominasi ini dimulai dengan pemberian mandat kepada militer untuk "memulihkan" keadaan nasional yang sedang kacau-balau. Melalui Kopkamtib dan BAKIN, militer memiliki akses tak terbatas untuk mengendalikan situasi, termasuk mengendalikan urusan-urusan politik dalam negeri.

Dominasi militer dalam menopang Orde Baru dimulai dengan penyingkiran kelas (komunis) di berbagai tempat secara sistematis. Tanah-tanah di desa-desa yang dimiliki basis petani komunis (BTI) direbut dan diduduki oleh militer, begitupun yang terjadi pada aktivis buruh di perusahaan perkebunan di Sumatera (SOBSI). Perebutan dan pendudukan ini, bukan cuma perkara luas tanah atau perkebunan, tapi menunjukkan perubahan secara radikal relasi kekuasaan yang sebelumnya menempatkan aktor sipil (petani dan buruh) sebagai aktor penting politik menjadi tunduk tanpa perlawanan di bawah militer. Setelahnya, kekuasaan militer dalam mengontrol urusan politik dalam negeri benar-benar mutlak.

Di awal pemerintahannya, Orde Baru memainkan pola restrukturisasi politik secara sistematis dalam rangka mengkonsolidasikan elemen-elemen kekuasaan serta menciptakan stabilitas politik yang terkendali guna menjamin berjalannya roda pembangunan. Dalam paradigma Orde Baru, pembangunan ekonomi tidak akan bisa berjalan tanpa adanya stabilitas politik. Sementara itu, stabilitas akan mudah tercapai jika dibarengi dengan format kekuasaan sentralistik untuk mempermudah kontrol terhadap berjalannya kekuasaan. Hal inilah yang mendasari Orde Baru untuk memilih model otoritarianisme dalam menjalankan kekuasaannya.

Salah satu masalah pokok yang ada dalam sistem pemerintahan Orde Baru adalah bagaimana menata sistem politik yang handal untuk mendukung pembangunan ekonomi serta bidangbidang lainnya. Oleh karena itu, langkah pertama yang diambil adalah konsolidasi politik pengendalian lewat birokrasi sipil dan militer. Seraya membenahi birokrasi, Orde Baru juga mengendalikan konflik di tubuh militer, terutama Angkatan Darat (AD). Penataan militer dilakukan secara sistematis, dimulai dengan pembersihan para perwira pro-Soekarno, hingga perubahan struktur organisasi ABRI. Untuk memperkuat keabsahan dominasi sistemik para perwira militer, diberlakukan doktrin dwi fungsi ABRI, di mana dalam hal ini, tentara Indonesia berbeda dengan tentara negara-negara lain, karena tentara Indonesia mengemban misi khusus, yakni tanggungjawab militer sekaligus tanggungjawab pada semua bidang yang penting bagi pelaksanaan negara. Melalui doktrin ini, militer merasa memiliki justifikasi untuk terlibat dalam bidang bidang non-militer yang lazimnya menjadi wilayah sipil. 


\section{KESIMPULAN}

Tahun-tahun pemerintahan Suharto diwarnai dengan praktik otoritarianisme di mana tentara memiliki peran dominan dalam banyak hal. Kebijakan dwifungsi ABRI telah membuka kesempatan kepada militer untuk berperan dalam bidang politik di samping perannya sebagai alat pertahanan negara. Demokrasi Pancasila yang dipopulerkan oleh Orde Baru harus diakui sebagai konsep demokrasi yang tereduksi bahkan tak ubahnya sebagai demokrasi semu karena dalam praktiknya justru membonsai kebebasan sipil.

Jalan otoritarianisme sengaja dipilih Soeharto dengan tujuan untuk mempermudah agenda-agenda pembangunan ekonomi. Dalam konteks ini, diperlukan stabilitas politik yang terkendali melalui format sentralisme politik untuk mempermudah alat kontrol bagi penyelenggaraan kekuasaan.

\section{DAFTAR PUSTAKA}

Alfian. (1990). Masalah dan Prospek Pembangunan Politik Indonesia. Jakarta: Gramedia.

Anderson, Bennedict. (1983). "Old State, New Society: Indonesia's New Order in Comparative Historical Perspective" , Journal of Asian Studies, Vol.XLII, No.3.

Bremmer. Ian (2013). The J Curve: Strategi Memahami Mengapa Bangsa-bangsa Berjaya dan Jatuh. Jakarta : Gramedia Pustaka Utama.

Crouch, Harold. (1986). Militer dan Politik di Indonesia, alih bahasa Th. Sumarthana, Jakarta: Sinar Harapan.

Crouch, Harold. (1995). "Masalah Dwi Fungsi ABRI", dalam Syamsudin Haris dan Riza Sihbudi (ed), Menelaah Kembali Format Politik Orde Baru. Jakarta: Gramedia Pustaka Utama.

Emmerson, Donald K. (1978). "The Bureaucracy in Political Context: Weakness in Strength", dalam Karl D. Jackson dan Lucian W. Pye (ed), Political Power and Communications in Indonesia. Berkeley and Los Angeles, California: University of California Press.
Gaffar, Afan. (1999). Politik Indonesia; Transisi Menuju Demokrasi, Yogyakarta: Pustaka Pelajar.

Gaffar, Afan. (2001). Dari Negara ke Negara: Perubahan Paradigma dalam Ilmu Politik. Yogyakarta: Pidato Pengukuhan Guru Besar pada FISIPOL UGM, 30 Juni 2001.

Hart, J. 't Hart, (1987). "Aspects of Criminal Justice", dalam Hans Thoolen, ed., Indonesia and the Rule of Law: Twenty Years of 'New Order' Government, London: Frances Pinter.

Jackson, Karl D. (1978). "Bureaucratic Polity: A Theoretical Framework for the Analysis of Power and Communication in Indonesia" , dalam Karl D. Jackson and Lucian W Pye (eds.), Political Power and Communication in Indonesia. Berkeley: University of California Press.

King, Dwight Y. (1982). "Indonesia's New Order as a Bureaucratic Polity, a Neopatrimonial Regime or Bureaucratic Authoritarian Regime: What Difference Does It Make?", dalam Benedict Anderson and A. Kahin, (eds)., Interpreting Indonesian Politic: Thirteen Conributions to the Debate. Ithaca: Cornell Modern Indonesia Project.

Liddle, R. William. (1985). "suharto's Indonesia: Personal Rule and Political Institutions", in PacificAffairs, 58, Spring.

Maclntyre, Andrew. (1990). Business and Politics in Indonesia, Sydney: Allen and Unwin.

Mansfield, Edward dan Snyder, Jack. (1995). "Democratization and The Danger of War," International Security, Vol. 20, No. 1, Summer.

Mas'oed, Mochtar. (1989). Ekonomi dan Struktur Politik Orde Baru 1966-1971. Jakarta: LP3ES.

Pratikno. (1998). Keretakan Otoritarianisme Orde Baru dan Propsek Demokratisasi. JSP. 2(2). November.

https://doi.org/10.22146/isp.11152, Diakses 30 November 2022

Robinson, Richard. (1988). Authoritarian states, capital-owning classes, and 
the politics of newly industrializing countries: The case of Indonesia, World Politics, 41(1), Oktober. https://doi.org/10.2307/2010479,

Diakses 30 November 2022 